\title{
Article \\ Phytochemical Analysis and Antioxidant, Antimicrobial, and Antiaging Activities of Ethanolic Seed Extracts of Four Mucuna Species
}

\author{
Tinnakorn Theansungnoen ${ }^{1,2}$, Nichcha Nitthikan ${ }^{3}$, Mayuramas Wilai ${ }^{1,4}$, Phanuphong Chaiwut ${ }^{1,2}$, \\ Kanokwan Kiattisin ${ }^{3,5, *}$ and Aekkhaluck Intharuksa ${ }^{3, *}$
}

check for

updates

Citation: Theansungnoen, T.;

Nitthikan, N.; Wilai, M.; Chaiwut, P.; Kiattisin, K.; Intharuksa, A.

Phytochemical Analysis and

Antioxidant, Antimicrobial, and

Antiaging Activities of Ethanolic

Seed Extracts of Four Mucuna Species.

Cosmetics 2022, 9, 14. https://

doi.org/10.3390/cosmetics 9010014

Academic Editor: Piera Di Martino

Received: 20 December 2021

Accepted: 17 January 2022

Published: 19 January 2022

Publisher's Note: MDPI stays neutral with regard to jurisdictional claims in published maps and institutional affiliations.

Copyright: (c) 2022 by the authors. Licensee MDPI, Basel, Switzerland. This article is an open access article distributed under the terms and conditions of the Creative Commons Attribution (CC BY) license (https:// creativecommons.org/licenses/by/ $4.0 /)$.
1 School of Cosmetic Science, Mae Fah Luang University, Chiang Rai 57100, Thailand; tinnakorn.the@mfu.ac.th (T.T.); mayuramas@mfu.ac.th (M.W.); phanuphong@mfu.ac.th (P.C.)

2 Green Cosmetic Technology Research Group, School of Cosmetic Science, Mae Fah Luang University, Chiang Rai 57100, Thailand

3 Department of Pharmaceutical Sciences, Faculty of Pharmacy, Chiang Mai University, Chiang Mai 50200, Thailand; nichcha_n@cmu.ac.th

4 Phytocosmetics and Cosmeceuticals Research Group, Mae Fah Luang University, Chiang Rai 57100, Thailand

5 Innovation Center for Holistic Health, Nutraceuticals, and Cosmeceuticals, Faculty of Pharmacy, Chiang Mai University, Chiang Mai 50200, Thailand

* Correspondence: kanokwan.k@cmu.ac.th (K.K.); aekkhaluck.int@cmu.ac.th (A.I.)

\begin{abstract}
The investigation into promising botanical materials for natural cosmetics is expanding due to environmental and health awareness. Here, we aimed to evaluate the phytochemical substances and the potential skin-related pharmacological activities of four Mucuna seeds, namely M. gigantea (Willd.) DC. (MGG), M. interrupta Gagnep. (MIT), M. monosperma Wight (MMM), and M. pruriens (L.) DC. (MPR), belonging to the Fabaceae family. In methodology, the Mucuna seeds were authenticated using morphological and molecular approaches. L-DOPA, phenolics, and flavonoid content, incorporated with HPLC and GC-MS fingerprinting analyses, were determined. Then, skin-related antimicrobial, antioxidant, and antiaging activities were determined. The results revealed that MPR showed the highest L-DOPA content (75.94 mg/100 mg extract), whereas MGG exhibited the highest phenolic and flavonoid content $(56.73 \pm 0.62 \mathrm{mg}$ gallic/g extract and $1030.11 \pm 3.97 \mathrm{mg}$ quercetin/g extract, respectively). Only MMM and MPR could inhibit all of S. aureus, S. epidermidis, and C. albicans, but no sample could inhibit $C$. acnes. Furthermore, all samples demonstrated antioxidant activity. Interestingly, all Мuсиna samples exhibited strong collagenase, elastase, and hyaluronidase inhibitory activities. We conclude that the ethanolic extracts of four Mucuna seeds are probably advantageous in the development of skincare cosmeceutical products.
\end{abstract}

Keywords: Mucuna; antiaging activity; antioxidant activity; antimicrobial activity; flavonoids; polyphenols

\section{Introduction}

The genus Mucuna, belonging to the Fabaceae family, is composed of approximately 115 species globally distributed in pantropical regions [1]. There are 14 taxa found in Thailand, including Mucuna bracteata DC., M. pruriens (L.) DC., M. gigantea (Willd.) DC., M. macrocarpa Wall., M. interrupta Gagnep., M. warburgii K. Schum. and Lauterb. (Figure 1) [2,3]. The members of this genus have been used in various fields, namely agriculture and foods, including medicines. For example, M. bracteata has been cultivated as green manure in the plantations of economic crops, such as maize, cotton, and rubber tree [4,5]. M. pruriens, an important species in this genus, has been utilized as a food source since its seeds contain a high protein content, around 25\% [6]. Therefore, populations, in some areas, consume both the green pods and the mature beans of $M$. pruriens by cooking or boiling them. Furthermore, the roasted and ground seeds of $M$. pruriens has been produced as a coffee substitute for at least several decades in Guatemala and Mexico [7]. In terms of medicinal 
usage, $M$. pruriens seeds have long been used to treat Parkinson's syndrome and increase libido in traditional Ayurvedic medicine [8,9]. M. pruriens, due to its benefits, is promoted in Thailand, i.e., the government encourages Thai agriculturists to increase their production (instead of rice) during times of drought, for domestic consumption and export.

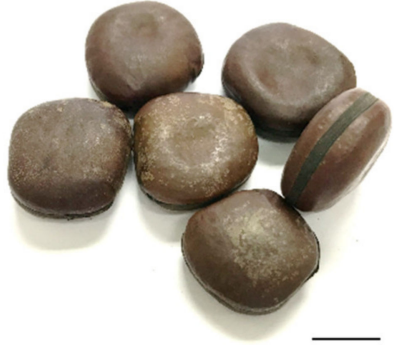

(a)

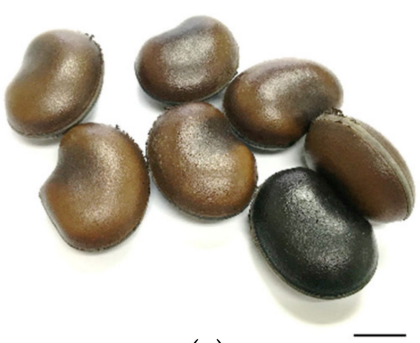

(c)

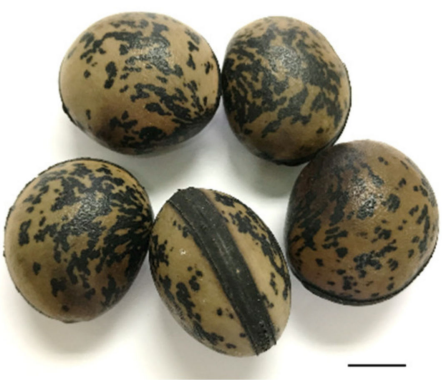

(b)

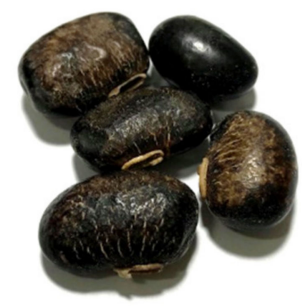

(d)

Figure 1. Characteristics of Mucuna seeds (a) M. gigantea (MGG), (b) M. interrupta (MIT), (c) M. monosperma (MMM), (d) M. pruriens (MPR). The indicated scale of each figure was $1 \mathrm{~cm}$ in length.

In 1937, levodopa (L-dihydroxyphenylalanine or L-DOPA), which is used effectively to manage the motor symptoms of Parkinson's disease, was firstly isolated from seeds of $M$. pruriens and has been found in other Mucuna species: M. bracteata, M. imbricata, $M$. macrocarpa, and M. mutisiana [10-13]. In addition, the seeds of M. pruriens contain various kinds of phytochemical substances, such as carbohydrates and amino acids, as well as anti-nutrient substances, such as polyphenols, phytates, tannins, and saponins [14,15]. Many biological studies have reported that $M$. pruriens possesses anti-Parkinson [16], antidiabetic [17], antioxidant [18,19], and antibacterial activities [20], as well as male fertility and aphrodisiac effects [21,22].

The skin is the largest organ and the outermost layer of the human body. It has many important functions, including protection against the environment, thermoregulation, and sensation [23]. Skin aging is caused by both intrinsic (an inevitable natural change due to the passage of time) and extrinsic factors (caused by external factors) [24,25]. The mechanisms of skin aging are related to oxidative stress from an imbalance between antioxidant and reactive oxygen species (ROS), mtDNA mutations, telomere shortening, changes in chromatin structure, the activation of oncogenes, epigenetic strands, as well as hormonal changes [26,27]. It is characterized by wrinkles, reduced elasticity, dry skin, hyperpigmentation, and harmful effects in the extracellular matrix (ECM). Collagen and elastin fibers are major components of the ECM, which provide tensile strength and elasticity, respectively. The total amount of collagen and elastin can be reduced with age by matrix metalloproteinases (MMPs), such as collagenase and elastase [28]. Moreover, skin aging is associated with loss of skin moisture that is related to hyaluronic acid (HA), a glycosaminoglycan (GAG) with a unique capacity to bind and retain water molecules [29]. HA has many functions, including hydration, the lubrication of joints, space-filling capacity, and providing the framework through which cells migrate [30]. HA can be degraded into fragments by hyaluronidases or a free-radical mechanism [31]. Therefore, inhibition of oxidative stress, MMPs, and hyaluronidase could be effective mechanisms to slow the skin's aging process and maintain its motorizing property. Besides aging skin, skin microbiota (or 
microflora) involves microorganisms that play a pivotal role to skin barrier function and maintain skin homeostasis. Imbalance of skin microorganisms (bacteria, fungi, viruses, and microeukaryotes) and barrier function can cause dysbiosis, leading to the occurrence of multiple skin disorders.

While investigating, in this era, the promising botanical materials for natural cosmetics, various plants have been evaluated for their efficacy and potentiality in developing high-valued plant-based ingredients for the cosmeceutical industries. However, cosmeceutical and skin-health-related literature of the Mucuna species, are limited. Therefore, to enhance supply chain management efficacy of $M$. pruriens seeds and add value to the underutilized $M$. gigantea, $M$. interrupta, and $M$. monosperma, in this study, we implemented the determination of phytochemical substances of four Mucuna seeds, namely L-DOPA, phenolics, and flavonoids. In addition, promising cosmeceutical properties, such as skinrelated antimicrobial, antioxidant, and antiaging-correlated activities, were analyzed and compared among four Mucuna species when searching for new potential active ingredients for cosmeceutical formulations.

\section{Materials and Methods}

\subsection{Collecting and Identification of Plant Materials}

The seeds of four Mucuna species were used in the study, namely Mucuna gigantea (Willd.) DC. (MGG), M. interrupta Gagnep. (MIT), M. monosperma Wight (MMM), and $M$. pruriens (L.) DC. (MPR) (Figure 1), gathered from local herbal markets (Table 1). Voucher specimens were deposited at the official herbarium of Faculty of Pharmacy, Chiang Mai University (CMU). The morphological characteristics of the Mucuna species were verified using the taxonomic key of Mucuna plants in Thailand [2], by Miss Wannaree Charoensup, the botanist at the Faculty of Pharmacy, Chiang Mai University.

Table 1. The collected Mucuna samples used in this study.

\begin{tabular}{cccc}
\hline Sample Codes & Expected Species & Collected Dates & $\begin{array}{c}\text { Localities } \\
\text { (District, Province) }\end{array}$ \\
\hline MGG & M. gigantea (Willd.) DC. & 24 November 2017 & Khuan Niang, Songkhla \\
MIT & M. interrupta Gagnep. & 10 June 2017 & Mae Sariang, Mae Hong Son \\
MMM & M. monosperma Wight & 24 May 2017 & $\begin{array}{c}\text { Mae Sot, Tak } \\
\text { MPR }\end{array}$ \\
M. pruriens (L.) DC. & 3 September 2017 & Ban Na Doem, Surat Thani \\
\hline
\end{tabular}

To confirm the genetic identity of each Mucuna samples, total genomic DNA of each Mucuna species was extracted from seed powder using DNeasy Plant Mini Kit (Qiagen, Hilden, Germany), according to the manufacturer's protocol, with minor modifications. The isolated DNA was amplified by PCR in the nuclear internal transcribed spacer 2 region. PCR was conducted in a final reaction volume, $25 \mu \mathrm{L}$, with a T960 PCR thermal cycler (Drawell, Chongqing, China). A total of 100-120 ng of genomic DNA was mixed with $12.5 \mu \mathrm{L}$ of $2 \times$ PCR Buffer for KOD FX Neo (Toyobo ${ }^{\circledR}$, Osaka, Japan), $5 \mu \mathrm{L}$ of each deoxyribonucleotide triphosphate (dNTP) $(0.4 \mathrm{mM}), 0.75 \mu \mathrm{L}$ each of S2F (ATGCGATACTTGTGTGAAT), and S3R (GACGCTTCTCCAGACTACAAT) $(0.15 \mu \mathrm{M})$ [32] and $0.5 \mu \mathrm{L}$ of KOD FX Neo DNA polymerase (0.5 unit). The PCR conditions were as follows: $94{ }^{\circ} \mathrm{C}$ for $2 \mathrm{~min}$; 30 cycles of $94{ }^{\circ} \mathrm{C}$ for $15 \mathrm{~s}, 55^{\circ} \mathrm{C}$ for $15 \mathrm{~s}$, and $58{ }^{\circ} \mathrm{C}$ for $45 \mathrm{~s} ; 65^{\circ} \mathrm{C}$ for $5 \mathrm{~min}$. The amplified PCR products were run in a 1.8\% agarose gel stained with RedSafe ${ }^{\mathrm{TM}}$ (Intron Biotechnology, Gyeonggi-do, Korea) and visualized under UV light using Gel Doc ${ }^{\mathrm{TM}}$ EZ Imager (Bio-Rad, Hercules, CA, USA). A MEGAquick-spin ${ }^{\mathrm{TM}}$ Plus Total Fragment DNA Purification Kit (Intron Biotechnology, Gyeonggi-do, Korea) was used to purify the accomplished PCR amplicons. Subsequently, the purified PCR products were sequenced using an ABI PRISM 3730 XL sequencer (Applied Biosystems, Waltham, MA, USA). The obtained nucleotide sequences were corrected using BioEdit software version 7.2.6 with manual modification and then aligned using MUSCLE software. To assure the identity of Mucuna samples, the nucleotide sequences were compared and matched to the reference nucleotide sequence 
database of the NCBI nucleotide database using the Basic Local Alignment Search Tool (BLAST) (www.blast.ncbi.nlm.nih.gov/Blast.cgi, accessed on 11 October 2021) with a minimum BLAST cut-off of $97 \%$ identity for a top match [33].

\subsection{Preparation of Mucuna Seed Extracts}

The Mucuna seeds were washed repeatedly and desiccated in a hot air oven at $55^{\circ} \mathrm{C}$ until totally dried. Subsequently, they were ground using an electrical blender. Seed powder of each Mucuna species (50 g) was extracted with ethanol using a Soxhlet apparatus at approximately $80^{\circ} \mathrm{C}$ for $5 \mathrm{~h}$. Crude extracts were processed through Whatman No. 1 paper filter and then evaporated by a rotary evaporator (EYELA, Tokyo, Japan). The HPLC and GC-MS chromatographic fingerprints were utilized for quality control of the seed extracts. The seed extracts were kept at $4{ }^{\circ} \mathrm{C}$ until use.

\subsection{Determination of L-DOPA Content}

The concentration of L-DOPA was evaluated following the protocol of Dhanani et al. with minor adjustments [19]. To compare the L-DOPA content and control the quality of the extracts, the powdered seeds of each Mucuna species were sieved, 100 mesh, and mixed with petroleum ether for separating lipid in their seeds, then refluxed using Soxhlet apparatus. Subsequently, the plant residue was added with the acidified water $\mathrm{pH} 2.5$ and refluxed for $5 \mathrm{~h}$. The supernatant was filtrated and concentrated using a vacuum rotary evaporator (EYELA, Tokyo, Japan). The L-DOPA content was quantified in the extract using HPLC (Shimadzu, Kyoto, Japan). The chromatographic separation was performed on RP-18 GP $(250 \times 4.6 \mathrm{~mm}, 5 \mu \mathrm{m})$. The mobile phase was a mixture of $0.1 \mathrm{~N}$ formic acid and methanol (98:2). The solvent flow rate was $1.0 \mathrm{~mL} / \mathrm{min}$. The injection volume was $10 \mu \mathrm{L}$. The photo diode array detector wavelength was set at $280 \mathrm{~nm}$. All experiments were conducted in triplicate. The concentration of L-DOPA was analyzed by comparison with the standard curve for the standard L-DOPA.

\subsection{Determination of Total Phenolic Content}

The amount of total phenolic compounds in the crude extracts was determined by using Folin-Ciocalteu reagent [34,35]. Gallic acid was used as a standard. A $5 \mathrm{mg} / \mathrm{mL}$ gallic acid stock solution was prepared by dissolving dry gallic acid in ethanol to DI water in ratio 2:3 for $1 \mathrm{~mL}$ and added to $10 \mathrm{~mL}$ volumetric flask, containing $9 \mathrm{~mL}$ of distilled water. The calibration curve of gallic acid (in concentrations of 0.01, 0.02, 0.03, 0.04, 0.05, $0.06,0.07,0.08,0.09,0.1,0.11$, and $0.12 \mathrm{mg} / \mathrm{mL}$ of gallic acid) was diluted. A concentration of $1 \mathrm{mg} / \mathrm{mL}$ of each extract was also prepared in 95\% ethanol, and $0.5 \mathrm{~mL}$ of each sample was mixed thoroughly with $2 \mathrm{~mL}$ of 10 -fold dilute Folin-Ciocalteu reagent. A total of $4 \mathrm{~mL}$ of $7.5 \%$ sodium carbonate was added, and then the mixture was allowed to stand for $30 \mathrm{~min}$ at room temperature. The absorbance was measured at $765 \mathrm{~nm}$ using a UV-Vis spectrophotometer (UV-2600i, Shimadzu, Kyoto, Japan). The total phenolic content of the extract was expressed as mg gallic acid equivalent/g dry weight extract. All experiments were performed in triplicate.

\subsection{Determination of Total Flavonoid Content}

The total flavonoid contents in the extracts were determined by the aluminum chloride colorimetric method [34]. A standard stock solution $(4 \mathrm{mg} / \mathrm{mL})$ of quercetin was prepared by dissolving $4 \mathrm{mg}$ of quercetin in $1 \mathrm{~mL}$ of absolute ethanol. The calibration curve of quercetin (in concentrations of $0.1,0.2,0.6,1.0,1.4,1.8,2.2$ and $2.6 \mathrm{mg} / \mathrm{mL}$ of quercetin) was diluted. A concentration of $1 \mathrm{mg} / \mathrm{mL}$ of each extract was also prepared in $95 \%$ ethanol and $1 \mathrm{~mL}$ of each sample was added to a $10 \mathrm{~mL}$ volumetric flask containing $4 \mathrm{~mL}$ of distilled water. At the same time, $0.3 \mathrm{~mL}$ of $5 \% \mathrm{NaNO}_{2}$ solution was added to the volumetric flask. After $5 \mathrm{~min}, 10 \% \mathrm{AlCl}_{3}$ solution was added, and the mixture was allowed to stand for another $1 \mathrm{~min}$ and $2 \mathrm{~mL}$ of $1 \mathrm{M} \mathrm{NaOH}$ was added to the mixture. Volume of the mixture was increased to $10 \mathrm{~mL}$ by immediately adding $2.4 \mathrm{~mL}$ of distilled water. Absorbance was 
measured at $510 \mathrm{~nm}$ using UV-Vis spectrophotometer (UV-2600i, Shimadzu, Kyoto, Japan). Total flavonoid content was expressed as $\mathrm{mg}$ quercetin equivalent/g dry weight extract, using the linear equation based on the calibration curve. All experiments were performed in triplicate.

\subsection{Gas Chromatography-Mass Spectrometry Analysis}

To analyze the phytochemicals and evaluate the chromatographic fingerprints in the seed extracts of each Mucuna species, the ethanolic extracts were separated by gas chromatography (Agilent 19091S-433, Agilent Technologies, Santa Clara, CA, USA) with GC column $(30 \mathrm{~m} \times 0.25 \mathrm{~mm} \times 0.25 \mu \mathrm{m})(\mathrm{HP}-5 \mathrm{MS}$ column, Agilent Technologies, Santa Clara, CA, USA). The temperature of the column oven was initially set to $60^{\circ} \mathrm{C}$ and it then increased to $290{ }^{\circ} \mathrm{C}$ for $10 \mathrm{~min}$. Seed extracts were diluted with absolute methanol and then injected by the spit sampling mode in the ratio of 1:10, and helium gas was used as a sample carrier with a flow rate of $1 \mathrm{~mL} / \mathrm{min}$ at $290^{\circ} \mathrm{C}$. The mass spectrum of each sample was shown after a solvent cutting time of $3 \mathrm{~min}$ and ended at $33 \mathrm{~min}$. The retention time (RT) and corrected area of peaks in each spectrum were generated by GC-MS software. The phytochemicals were identified via the retention time (RT) of the eluted peaks on the GC column as well as the mass spectra (MS), matching with NIST library databases. Main compounds present in the antimicrobial and antioxidant extracts were identified.

\subsection{Antimicrobial Activity Assay}

The antimicrobial activity of Mucuna seed extracts was measured by a broth microdilution assay modified from the protocol of Yaraksa et al. [36] against common skin pathogen, including three bacterial strains (Staphylococcus aureus TISTR 746, Staphylococcus epidermidis TISTR 2141, and Cutibacterium acnes DMST 14916) and a yeast (Candida albicans TISTR 5239). Seed extracts were dissolved individually in 5\% DMSO and subsequently prepared the final concentrations in the range of $0.51-16.40 \mathrm{mg} / \mathrm{mL}$. Microbial cells were cultured in a nutrient broth or brain-heart infusion broth to the log phase and then diluted to a cell density of $\sim 1 \times 10^{6} \mathrm{cfu} / \mathrm{mL}$ ). Briefly, $10 \mu \mathrm{L}$ of each Mucuna seed extract was added to $0.1 \mathrm{~mL}$ of the microbial cell solution in a 96-well plate. The tests against $S$. aureus, $S$. epidermidis, and C. albicans were incubated aerobically for $20 \mathrm{~h}$ at $37^{\circ} \mathrm{C}$, while the tests against $C$. acnes were incubated without oxygen for $72{ }^{\circ} \mathrm{C}$, at the same temperature. Positive and negative controls were tetracycline and 5\% DMSO, respectively. The antimicrobial efficiency of Mucuna seed extracts was investigated by the resazurin reduction. A total of $20 \mu \mathrm{L}$ of $0.06 \%$ resazurin solution was added to each test for $6 \mathrm{~h}$. The minimal inhibitory concentration (MIC) was defined as the lowest concentration of Mucuna seed extracts that could not cause the colorization of resazurin agent. The minimum bactericidal concentration or fungicidal concentration (MBC or MFC) was investigated using the single streak method and defined as the lowest concentration of Mucuna seed extracts that could not observe any colony.

\subsection{Antioxidant Activity Assay}

\subsubsection{1,1-Diphenyl-2-Picrylhydrazyl (DPPH) Radical Scavenging Assay}

The antioxidant efficiency of Mucuna seed extracts was investigated by DPPH assay [37] and evaluated via the half-maximal inhibitory concentration (IC50) value. DPPH solution at a concentration of $0.1 \mathrm{mM}$ was prepared in absolute methanol. Then, $100 \mu \mathrm{L}$ of Mucuna seed extract was added individually to $1 \mathrm{~mL}$ of the DPPH solution. The reaction was mixed well and incubated further in a dark area for $30 \mathrm{~min}$. The DPPH radical scavenging ability of Mucuna seed extract was measured at a wavelength of $517 \mathrm{~nm}$ using a UV-Vis spectrophotometer. Triplicate determinations of each reaction were performed. Ascorbic acid was used as a positive control and a DPPH solution without a sample was 
used as a control. The inhibitory percentage of the DPPH radical scavenging ability was calculated following the formula:

$$
\% \text { inhibition }\left(\left(\text { Control }_{\mathrm{A} 517 \mathrm{~nm}}-\text { Sample }_{\mathrm{A} 517 \mathrm{~nm}}\right) / \text { Control }_{\mathrm{A} 517 \mathrm{~nm}}\right) \times 100
$$

\subsubsection{Ferric Reducing Antioxidant Power (FRAP) Assay}

The reducing capacity of Mucuna seed extracts was investigated by the ferric reducing antioxidant power assay [38]. The FRAP reagent contained $50 \mathrm{~mL}$ of a $300 \mathrm{mM}$ acetate buffer, $5 \mathrm{~mL}$ of $10 \mathrm{mM}$ 2,4,6-Tris(2-pyridyl)-s-triazine (TPTZ) dissolved in $40 \mathrm{mM}$ of $37 \% \mathrm{v} / \mathrm{v}$ $\mathrm{HCl}$ and $5 \mathrm{~mL}$ of $20 \mathrm{mM}$ ferric chloride solution. Then, $20 \mu \mathrm{L}$ of Mucuna seed extracts were mixed with $180 \mu \mathrm{L}$ of FRAP reagent and incubated at room temperature for $5 \mathrm{~min}$. After, the mixture's absorbance was measured at $593 \mathrm{~nm}$ using a microplate reader (SPECTROstar Nano, UK). The experiment was performed in triplicate. Ascorbic acid was used as a positive control. The result was expressed as a FRAP value or $\mathrm{FeSO}_{4}$ equivalent per gram of sample.

\subsubsection{Lipid Peroxidation Inhibition Assay Using Linoleic Acid Thiocyanate Method}

The lipid peroxidation inhibition property of Mucuna seed extracts was determined using the linoleic acid thiocyanate method, by following the method of Nitthikan [38], with some modifications. DI water $(175 \mu \mathrm{L}), 20 \mathrm{mM}$ phosphate buffer $\mathrm{pH} 7.0(350 \mu \mathrm{L})$, and $1.3 \% v / v$ linoleic acid in methanol $(350 \mu \mathrm{L})$ were mixed with an aliquot of Mucuna extract (75 $\mu \mathrm{L}$ ). Then, $46.35 \mathrm{mM}$ 2,2'-Azobis(2-amidinopropane) dihydrochloride (AAPH) at $50 \mu \mathrm{L}$ was added and incubated in water bath at $45^{\circ} \mathrm{C}$ for $4 \mathrm{~h}$. After, the sample was mixed with $20 \mathrm{mM}$ ferrous chloride solution $(50 \mu \mathrm{L}), 10 \%$ ammonium thiocyanate solution $(50 \mu \mathrm{L})$ and $75 \%$ methanol $(4.85 \mathrm{~mL})$ for $3 \mathrm{~min}$ in test tube. The absorbance was measured at $500 \mathrm{~nm}$ using UV-Visible spectrophotometer (UV-1800 SHIMADZU). Ascorbic acid was used as a positive control. The results are reported as $\mathrm{IC}_{50}$ values. The percentage inhibition of lipid peroxidation was calculated with the following formula:

$$
\text { Inhibition }=\left(\left(\text { Control }_{\mathrm{A} 500 \mathrm{~nm}}-\text { Sample }_{\mathrm{A} 500 \mathrm{~nm}}\right) / \text { Control }_{\mathrm{A} 500 \mathrm{~nm}}\right) \times 100
$$

\subsection{Hyaluronidase Inhibitory Assay}

Hyaluronidase inhibitory activity was determined by the turbidimetric method according to Widowati and colleagues' protocol with some modifications [39]. Hyaluronic acid can be precipitated with albumin acid solution and generate turbidity solution. The turbidity of the sample is related to the hyaluronic acid concentration and hyaluronidase activity. The hyaluronidase activity was determined before performing each experiment, and only more than $90 \%$ enzyme activity was used in the experiment. Briefly, $50 \mu \mathrm{L}$ of each sample at concentration $1 \mathrm{mg} / \mathrm{mL}$ was incubated with $100 \mu \mathrm{L}$ of hyaluronidase ( 800 units $/ \mathrm{mL}$ ) from bovine testis (E.C. 3.2.1.3.5) in enzyme diluent at $37.5^{\circ} \mathrm{C}$ for $10 \mathrm{~min}$ in water bath (Memmert $\mathrm{GmbH}$, Büchenbach, Germany). After, $100 \mu \mathrm{L}$ of $0.03 \%(w / v)$ hyaluronic acid in phosphate buffer ( $\mathrm{pH}$ 5.35) was added and then incubated for $45 \mathrm{~min}$. After incubation, $1 \mathrm{~mL}$ of bovine serum albumin acid solution that consisted of $24 \mathrm{mM}$ sodium acetate, $79 \mathrm{mM}$ acetic acid, and $0.1 \%(w / v)$ bovine serum albumin ( $\mathrm{pH} 3.75)$, was added into the mixture to precipitate the hyaluronic acid. The mixture solution was incubated at room temperature for $10 \mathrm{~min}$. The absorbance at $600 \mathrm{~nm}$ was measured using a microplate reader (SPECTROstar Nano, BMG Labtech, Aylesbury, UK). All experiments were performed in triplicate. The inhibition of hyaluronidase was calculated by using following equation:

$$
\% \text { Hyaluronidase inhibition }=\left(\left(\mathrm{Abs}_{\text {control }}-\left(\mathrm{Abs}_{\text {sample }}-\mathrm{Abs}_{\text {blank sample }}\right)\right) / \mathrm{Abs}_{\text {control }}\right) \times 100
$$

where $\mathrm{Abs}_{\text {control }}$ is the absorbance of the mixture containing hyaluronidase, hyaluronic acid, and bovine serum albumin acid solution. Abs sample is the absorbance of the mixture containing sample, hyaluronidase, hyaluronic acid, and bovine serum albumin acid solu- 
tion. $\mathrm{Abs}_{\text {blank sample }}$ is the absorbance of the mixture without hyaluronidase. Ascorbic acid and L-DOPA were used as a positive control.

\subsection{Collagenase Inhibitory Activity}

Collagenase inhibitory activity was performed according to Thring et al.'s protocol, with few modifications [40]. The collagenase inhibition was evaluated by measuring the decrease in FALGPA (substrate). The collagenase activity was determined before performing each experiment, and only more than $90 \%$ enzyme activity was used in the experiment. In this assay, $10 \mu \mathrm{L}$ of sample $(1 \mathrm{mg} / \mathrm{mL})$ was incubated with $40 \mu \mathrm{L}$ of collagenase enzyme (0.25 units $/ \mathrm{mL}$ ) from Clostridium histolyticum (ChC-E.C. 3.3.23.3) in tricine buffer ( $\mathrm{pH} 7.5$ ) for $15 \mathrm{~min}$ at room temperature. After incubation, $50 \mu \mathrm{L}$ of $2 \mathrm{mM}$ FALGPA in tricine buffer was added to the mixture. The absorbance of the mixture was immediately measured after adding FALGPA solution and continuously measured at $335 \mathrm{~nm}$ for $20 \mathrm{~min}$ with kinetic mode using a microplate reader (SPECTROstar Nano, BMG Labtech, Aylesbury, UK). All experiments were performed in triplicate. The inhibition of collagenase was calculated by using following equation:

$$
\% \text { Collagenase inhibition }=((\mathrm{A}-\mathrm{B}) / \mathrm{A}) \times 100
$$

where $\mathrm{A}$ is the reaction rate of the mixture containing collagenase and substrate. $\mathrm{B}$ is the reaction rate of the mixture containing sample, collagenase, and substrate. Epigallocatechin gallate (EGCG) and L-DOPA were used as positive controls.

\subsection{Elastase Inhibitory Activity}

The inhibition of elastase was measured from the reaction of elastase and AAAVPN (substrate), according to the protocol of Thring et al., with some modifications [40]. The elastase activity was determined before performing each experiment, and only more than $90 \%$ enzyme activity was used in the experiment. Briefly, $50 \mu \mathrm{L}$ of sample $(1 \mathrm{mg} / \mathrm{mL})$ was mixed with $25 \mu \mathrm{L}$ of $4.4 \mathrm{mM}$ AAAVPN in Tris-HCl buffer ( $\mathrm{pH}$ 8.0) and then incubated at room temperature for $20 \mathrm{~min}$. After incubation, $25 \mu \mathrm{L}$ of elastase $(0.05$ units $/ \mathrm{mL})$ from porcine pancreas (E.C. 3.4.21.11) in Tris-HCl buffer was added into the mixture. The absorbance of the mixture was immediately measured after adding AAAVPN solution and continuously measured at $410 \mathrm{~nm}$ for $20 \mathrm{~min}$ with a kinetic mode using a microplate reader (SPECTROstar Nano, BMG Labtech, Aylesbury, UK). All experiments were performed in triplicate. The inhibition of elastase was calculated by using the following equation:

$$
\% \text { Elastase inhibition }=((\mathrm{A}-\mathrm{B}) / \mathrm{A}) \times 100
$$

where $\mathrm{A}$ is the reaction rate of the mixture containing elastase, Tris- $\mathrm{HCl}$ buffer, and substrate. $B$ is the reaction rate of the mixture containing sample, elastase, Tris- $\mathrm{HCl}$ buffer, and substrate. Epigallocatechin gallate (EGCG) and L-DOPA were used as positive controls.

\subsection{Statistical Analysis}

All results are expressed as the mean \pm SD. The results were statistically compared by one-way ANOVA with multiple comparisons using Tukey's test (GraphPad Prism version 8). Significant differences were considered at $p<0.05$.

\section{Results and Discussions}

\subsection{Identification of Plant Materials Using a Mini-Barcode, ITS2 Intergenic Region}

The DNA- based authentication was suggested to be an efficient implementation for safety monitoring and quality control of herbal medicine, pharmaceutical, and nutraceutical products, including cosmetics [41,42]. The second internal transcribed spacer of nuclear ribosomal DNA (ITS2) has been recommended as a 'gold standard' barcode for identifying medicinal plants and their close-related species because it provided potentially discriminatory power in a broad range of plant taxa [32,43]. In our work, to confirm the 
morphological identification of samples, molecular identification using DNA barcoding was implemented to verify the identity of four Mucuna samples. The nucleotide sequences of the nuclear ITS2 intergenic region, as a mini barcode, were analyzed. We sequenced the nucleotide sequences of all Mucuna samples (Figure S1, Supplementary Materials). The results of BLAST-similarity-based identification are presented in Table 2. The nucleotide sequences of the ITS2 region of all four Mucuna samples showed similarity to the reference sequences in the DDBJ/EML/GenBank database. Considering the best max score and percent identity, the results revealed that MGG, MIT, MMM, and MPR originated from $M$. gigantea, M. interrupta, $M$. monosperma, and $M$. pruriens, respectively. Therefore, our study agrees with Rashmi and colleague's work, in that ITS2 is suitable to differentiate the closely related Mucuna species [44].

Table 2. The BLAST results of four Mucuna seeds.

\begin{tabular}{ccccc}
\hline Sample Codes & $\begin{array}{c}\text { Species of } \\
\text { BLAST Results }\end{array}$ & $\begin{array}{c}\text { Accession } \\
\text { Number }\end{array}$ & Max Score & $\begin{array}{c}\text { Percent Identity } \\
\text { (\%) }\end{array}$ \\
\hline MGG & M. gigantea & LC494611 & 612 & 99.11 \\
MIT & M. interrupta & HM355841 & 675 & 98.94 \\
MMM & M. monosperma & AB775135 & 625 & 98.06 \\
MPR & M. pruriens & KX057890 & 730 & 99.50 \\
\hline
\end{tabular}

\subsection{Determination of L-DOPA and, Total Phenolic, and Flavonoid Content}

To compare the phytochemical substances in four authenticated Mucuna seeds, LDOPA, a major compound found in Mucuna seeds, and total phenolic and flavonoid content were evaluated. The data analyzed from HPLC were compared with the calibration curve of the L-DOPA standard. The calibration curve exhibited good linearity with correlation coefficients $\left(\mathrm{R}^{2}\right)$ : 1.000 . Figure 2 illustrates that MPR showed the tallest peak in the fingerprint of the HPLC chromatogram. Based on the data obtained, the highest L-DOPA content was found in MPR (75.94 mg/100 mg extract), followed by MGG (31.52 mg/100 mg extract), MMM (5.35 mg/100 mg extract), and MIT (3.31 mg/100 mg extract).

The total phenolic and total flavonoid content of Mucuna seed extracts divided by species are shown in Figure 3. Surprisingly, the results showed that the MGG seed extract had the significantly highest content of both total phenolic and total flavonoids. In the case of total phenolic content, MGG had the highest quantity (56.73 $\pm 0.62 \mathrm{mg}$ gallic $/ \mathrm{g}$ dry weight extract), followed by MMM, MPR, and MIT (29.36 $\pm 0.84,21.78 \pm 3.58$, and $9.27 \pm 0.26 \mathrm{mg}$ gallic acid/g dry weight extract, respectively). Moreover, MGG also had the highest total flavonoid content $(1030.11 \pm 3.97 \mathrm{mg}$ quercetin/g dry weight extract), followed by MPR, MIT, and MMM (423.48 $\pm 6.71,422.26 \pm 4.20$, and $32.93 \pm 2.93 \mathrm{mg}$ quercetin/g dry weight extract, respectively). The amount of phenolic and total flavonoid content of each extract depended on the polarity of the extracting solvent used in the extraction process [45]. Phenolic compounds are mostly hydrophilic; therefore, they were more easily extracted by polar solvents. In contrast, flavonoid compounds are mostly hydrophobic, so they could be easily extracted by semi-polar solvents. Therefore, all ethanolic Mucuna seed extracts were composed of total flavonoid content higher than the total phenolic content related to the extracting solvent. 

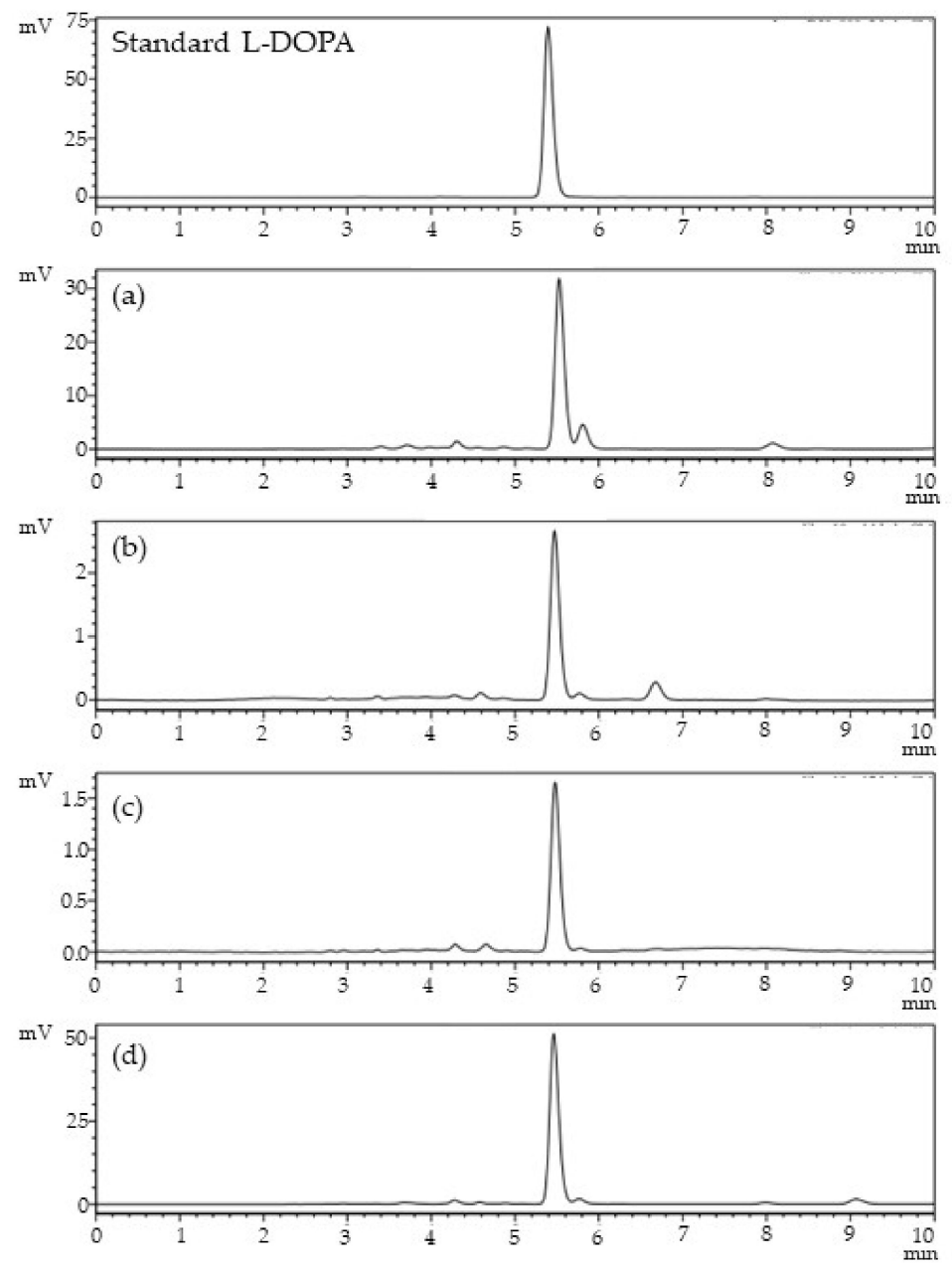

Figure 2. HPLC chromatograms of L-DOPA extracted from (a) MGG, (b) MIT, (c) MMM, and (d) MPR.

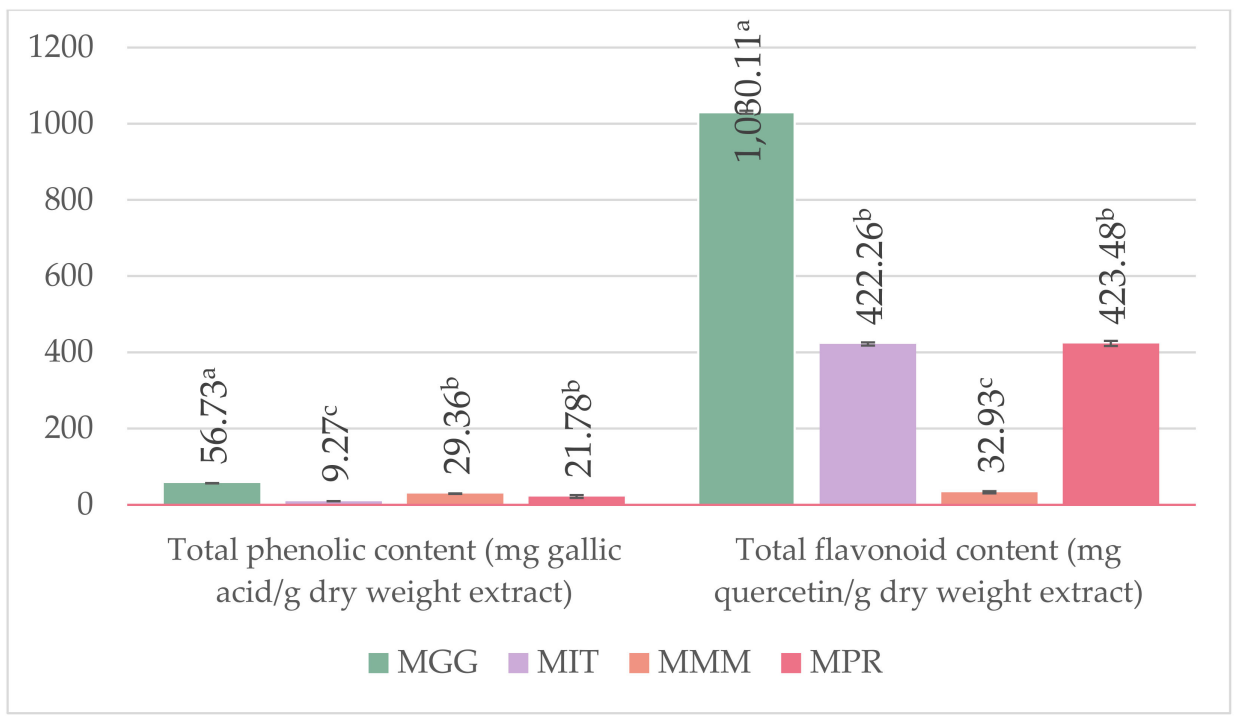

Figure 3. Total phenolic and total flavonoid contents of Mucuna seed extracts. Values are expressed as mean $\pm \mathrm{SD}(n=3) ; \mathrm{a}, \mathrm{b}$, and c show significant differences among samples at $p<0.05$. 


\subsection{Phytochemical Analysis Using GC-MS}

The volatile compounds of ethanolic extracts of four Mucuna samples were measured by the GC-MS technique. GC chromatograms for MGG, MIT, MMM, and MPR are shown in Figure 4. The mass spectra in each chromatogram were identified via matching with the database in NIST libraries, and the phytochemical constituents in each Mucuna seed extract were matched and are shown in Figure 4 and Table S1, Supplementary Materials. As depicted in Figure 4a, the four compounds in MGG ranking from the lowest to highest retention time (RT) were azetidine (6.79), 2,4-di-tert-butylphenol acetate (12.36), 2-propenenitrile, 2-chloro- (16.86), and methylurea (18.77). The four compounds found in MIT were undecane (6.01), 2-amino-6-cholo-3-cyano-5-(3-methyl-1-butenyl)pyrazine (19.78), bis(2-ethylhexyl) phthalate (21.65), and hexamethylcyclotrisiloxane (23.39) (Figure 4b). The seed extract of MMM showed eight compounds namely undecane (6.01), maltol (6.29), cytidine (11.07), resorcinol (14.47), palmitic acid (16.48), dodecanamide, N(2-hydroxyethyl) (18.19), 5-(Npiperidyl)-4-oxopentanoic acid piperidide (19.78), and bis(2-ethylhexyl) phthalate (21.66), as illustrated in Figure 4c. Similar to MMM, eight compounds were found in MPR: 1,2,3propanetriol, monoacetate (6.07), butyl 2-methyl butanoate (8.07), palmitic acid (16.49), linoleic acid (18.15), stearic acid (18.38), 4-hydroxy-2,2,6-trimethylcyclohex-2-enone (19.74), 2-ethylacridine (21.14), and bis(2-ethylhexyl) phthalate (21.66) (Figure 4d). As the results of the matched chemical substances, hexamethylcyclotrisiloxane, which was found in MIT, showed antioxidant, anti-lung cancer, and antibacterial activities [46]. The undecane found in MIT and MMM was detected in the essential oil of the Halimodendron halodendron flower. It was reported that it exhibited antimicrobial and antioxidant activities [47]. A palmitic acid found in MMM and MPR manifested antioxidant activities on DPPH and ABTS radicals [48]. Babiwa and co-worker reported that 1,2,3-propanetriol, monoacetate containing in Citrullus lanatus and MPR seed exhibited antimicrobial activity against Pseudomonas aeruginosa, Escherichia coli, Bacillus subtilis, S. aureus, and C. albicans [49]. Furthermore, 2,4di-tert-butylphenol, the matched chemical substance detected in MGG, was reported that to possess DPPH free radical scavenging activity, total antioxidant capacity (Trolox equivalent antioxidant capacity), and reducing ability [50]. Furthermore, azetidine-derived carbamate was reported to inhibit monoacylglycerol lipase, a $33 \mathrm{kDa}$ serine hydrolase [51]. Therefore, azetidine in MGG may have facilitated the inhibitory activities against collagenase and elastase, which are serine protease.

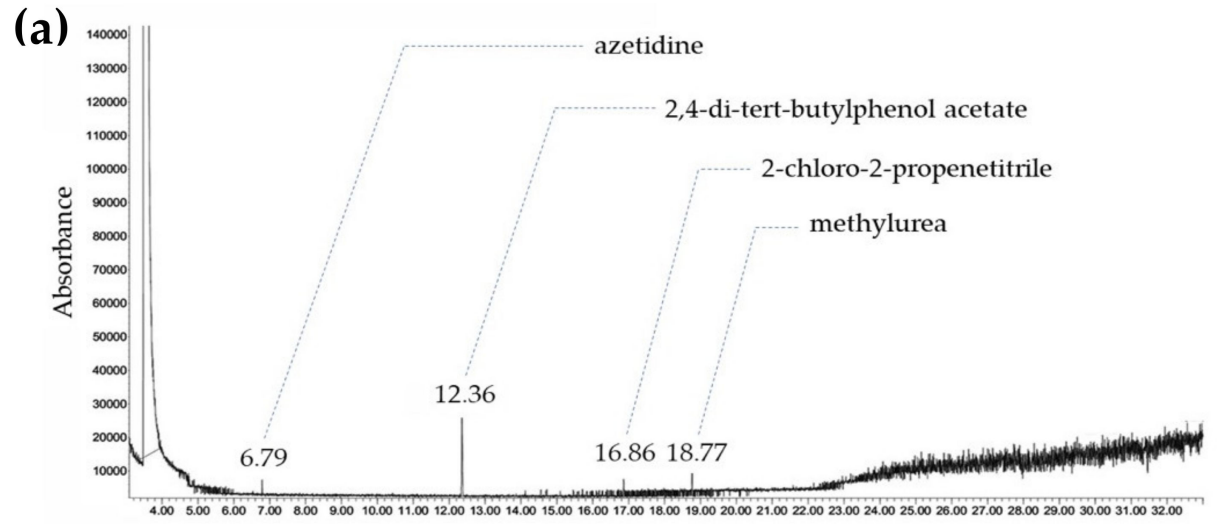

Figure 4. Cont. 

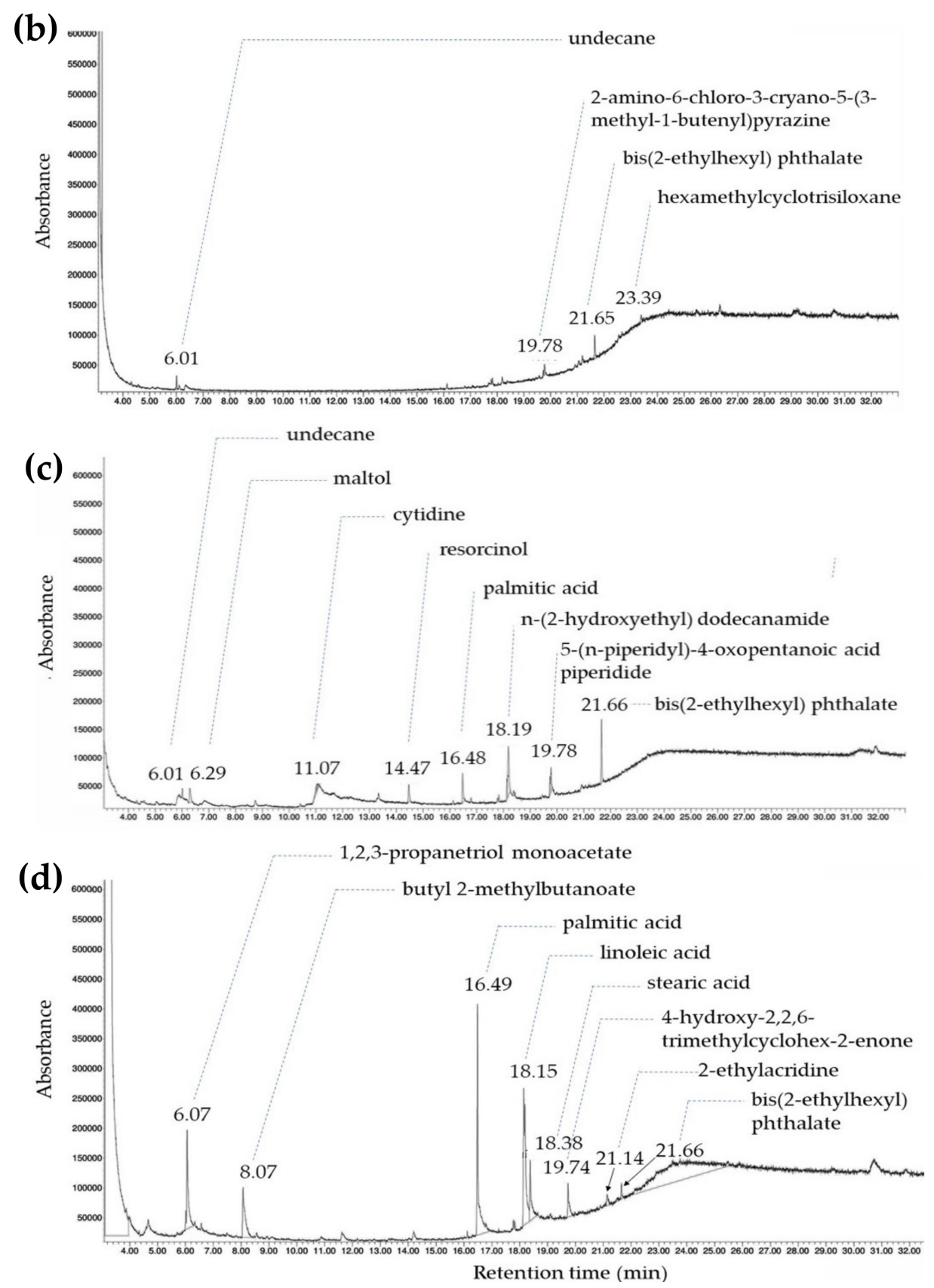

Figure 4. GC-MS chromatograms of ethanolic seed extracts belonged to four Mucuna species. (a) $M$. gigantea (MGG), (b) M. interrupta (MIT), (c) M. monosperma (MMM), (d) M. pruriens (MPR).

\subsection{Skin-Related Antimicrobial Activities}

The antimicrobial activity of four Mucuna seed extracts was further evaluated. As shown in Table 3 and Figure S2 (Supplementary Materials), the ethanolic seed extract of MMM could inhibit $S$. aureus, $S$. epidermidis, and $C$. albicans with the bacteriostatic indices (MICs) and bactericidal or fungicidal indices (MBCs or MFCs) being 8.20 and $16.40 \mathrm{mg} / \mathrm{mL}$, 8.20 and $16.40 \mathrm{mg} / \mathrm{mL}$, and 4.10 and $8.20 \mathrm{mg} / \mathrm{mL}$, respectively. The efficiencies of the ethanolic seed extract of MPR against $S$. aureus were $4.10 \mathrm{mg} / \mathrm{mL}$ for the MICs and MBCs, while those of MIT against C. albicans were $8.20 \mathrm{mg} / \mathrm{mL}$ for the MICs and $16.40 \mathrm{mg} / \mathrm{mL}$ for the MFCs. However, the MIC and MBC or MFC values of the ethanolic extract of the MGG seeds were undetectable for S. aureus, S. epidermidis, and C. albicans. Furthermore, in our study, the results showed that no extracts of Mucuna seeds could inhibit $C$. acnes. Nevertheless, among Mucuna seed extracts, ethanolic extract of MMM seeds possessed a 
promising broad spectrum of antimicrobial activity against some infectious skin pathogens. From the previous study, the methanolic extracts of $M$. monosperma seed kernel in 2.5, 5, and $7.5 \mathrm{mg} /$ disc exhibited the potential to inhibit various bacteria, namely B. subtilis NCIM2063, E. coli NCIM-2065, Enterobacter aerogenes NCIM-2340, Alcaligenes faecalis NICM-2262, S. aureus NICM-2079, P. aeruginosa NICM-2036, Proteus vulgaris NICM-2027, and B. cereus NICM-2155 [52]. Shanmugavel and Krishnamoorthy's work revealed that the alcoholic extract of M. pruriens seeds could inhibit Vibrio harveyi, V. cholera, E. coli, and S. aureus using the disc diffusion method [20]. Furthermore, scientific literatures on antimicrobial activity describes the evaluation of the seed extract of Mucuna spp. For example, the methanolic and ethyl acetate seed extract of $M$. cochinchinensis showed antimicrobial potency against $E$. coli, Klebsiella pneumonia, P. vulgaris, B. subtilis, S. aureus, Aspergillus niger, and C. albicans, according to the disc diffusion method [53]. As mentioned above, Mucuna seed extracts, especially MMM, could be used as alternative ingredients in cosmeceutical product-related acne or skin inflammation. Even though Mucuna seed extracts could not inhibit C. acnes; however, they have potential to inhibit $S$. aureus and S. epidermidis associated with inflamed acne lesions.

Table 3. Antimicrobial activities of four Mucuna seed extracts evaluated by the broth microdilution assay.

\begin{tabular}{|c|c|c|c|c|c|c|c|c|}
\hline \multirow{2}{*}{ Extracts } & \multicolumn{2}{|c|}{$\begin{array}{c}\text { C. acnes } \\
\text { DMST } 14916\end{array}$} & \multicolumn{2}{|c|}{$\begin{array}{c}\text { S. aureus } \\
\text { TISTR } 746\end{array}$} & \multicolumn{2}{|c|}{$\begin{array}{c}\text { S. epidermidis } \\
\text { TISTR } 2141\end{array}$} & \multicolumn{2}{|c|}{$\begin{array}{l}\text { C. albicans } \\
\text { TISTR } 5239\end{array}$} \\
\hline & $\begin{array}{c}\text { MIC } \\
(\mathrm{mg} / \mathrm{mL})\end{array}$ & $\begin{array}{c}\mathrm{MBC} \\
(\mathrm{mg} / \mathrm{mL})\end{array}$ & $\begin{array}{c}\text { MIC } \\
(\mathrm{mg} / \mathrm{mL})\end{array}$ & $\begin{array}{c}\mathrm{MBC} \\
(\mathrm{mg} / \mathrm{mL})\end{array}$ & $\begin{array}{c}\text { MIC } \\
(\mathrm{mg} / \mathrm{mL})\end{array}$ & $\begin{array}{c}\text { MFC } \\
(\mathrm{mg} / \mathrm{mL})\end{array}$ & $\begin{array}{c}\mathrm{MIC} \\
(\mathrm{mg} / \mathrm{mL})\end{array}$ & $\begin{array}{c}\text { MBC } \\
(\mathrm{mg} / \mathrm{mL})\end{array}$ \\
\hline MGG & $N d$. & $N d$. & $N d$. & $N d$. & $N d$. & $N d$. & $N d$. & $N d$. \\
\hline MIT & $N d$. & $N d$. & $N d$. & $N d$. & $N d$. & $N d$. & 8.20 & 16.40 \\
\hline MMM & $N d$. & $N d$. & 8.20 & 16.40 & 8.20 & 16.40 & 4.10 & 8.20 \\
\hline MPR & $N d$. & $N d$. & 4.10 & 4.10 & $N d$. & $N d$ & $N d$. & $N d$ \\
\hline
\end{tabular}

$\mathrm{Nd}$. means not detected in the Mucuna seed extracts, which ranged from 0.51 to $16.40 \mathrm{mg} / \mathrm{mL}$.

\subsection{Antioxidant Activity Assay}

The antioxidant activities of plant extracts are influenced by various mechanisms, which can be detected by more than one method. Antioxidants can prevent oxidation reaction and oxidative stress by a free radical scavenger, chain-breaking reaction, and deactivation of metals. The antioxidant activities of Mucuna seed extracts were evaluated via a DPPH scavenging activity assay, FRAP assay, and lipid peroxidation inhibition assay. In the DPPH assay, all ethanolic extracts possessed antioxidant activity, and MMM showed the highest IC50 value $(2.38 \mu \mathrm{g} / \mathrm{mL})$, succeeded by MIT, MPR, and MGG at IC50: 6.73, 6.88 and $32.37 \mu \mathrm{g} / \mathrm{mL}$, respectively, as illustrated in Figure 5. However, the antioxidative data of M. monosperma was limited, but there is some scientific literature on M. pruriens. In 2015, Dhanani et al. reported that an extract carried out with water-hydrochloric acid $(0.1 \mathrm{~N})$ of $M$. pruriens seed presented significant antioxidative activity using a DPPH scavenging activity assay [19]. Likewise, the research outcomes of antioxidant activity analyzed in the freezedried seed extract of $M$. pruriens demonstrated that $M$. pruriens presented antioxidative properties by using a phosphomolybdenum complex assay, DPPH, and 2,2'-azinobis(3ethylbenzothiazoline-6-sulfonate (ABTS) radical scavenging analysis [54]. Furthermore, the water extract of $M$. pruriens beans exhibited antioxidant activity via DPPH radicals, ABTS radicals, and reactive oxygen species and the inhibition of the oxidation of lipids and deoxyribose sugar [55]. 


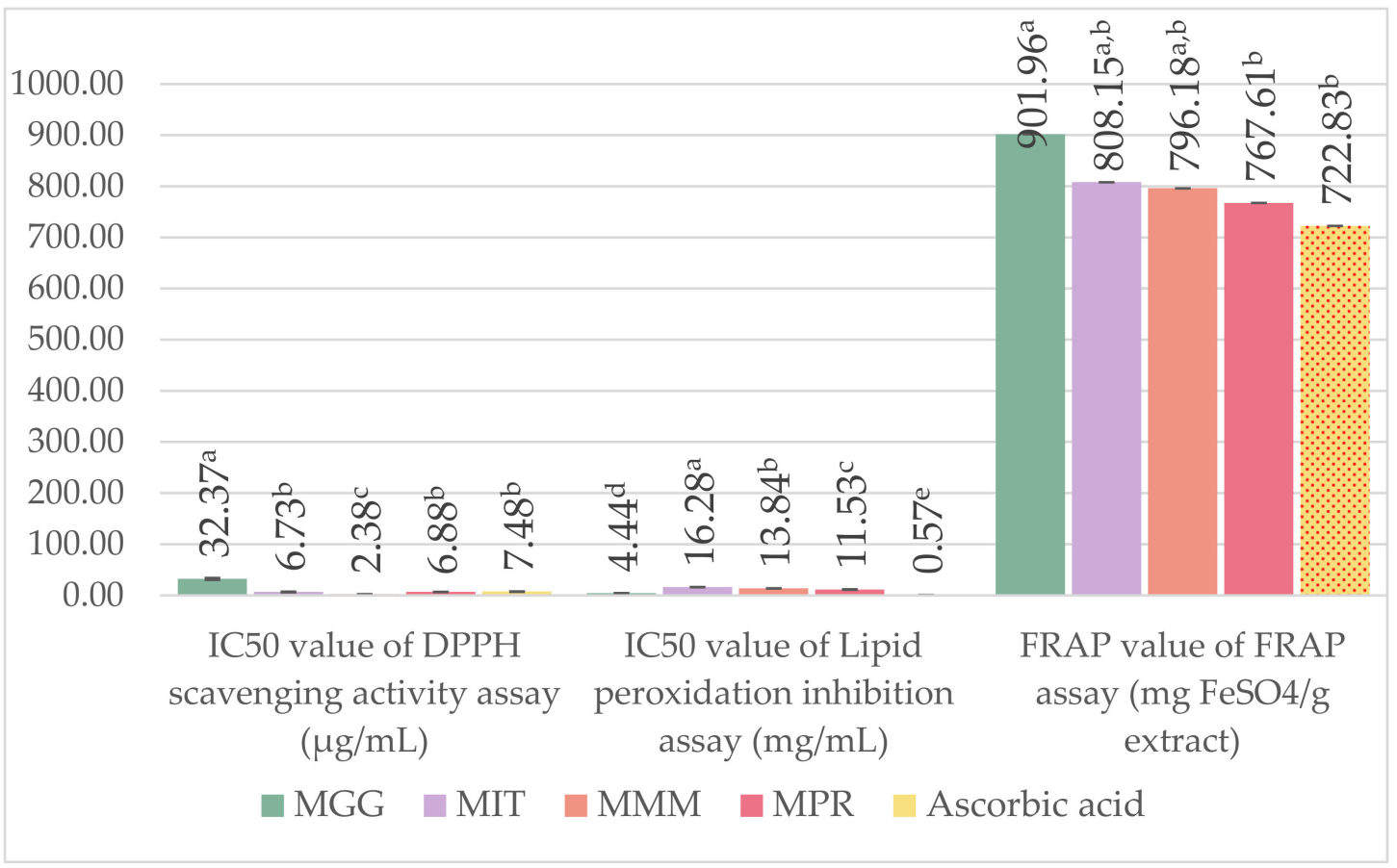

Figure 5. IC50 of DPPH scavenging activity assay and lipid peroxidation inhibition assay, FRAP value of FRAP assay of four Mucuna seed extracts compared with ascorbic acid. Values are expressed as mean $\pm \mathrm{SD}(n=3) ; \mathrm{a}, \mathrm{b}, \mathrm{c}, \mathrm{d}$, and e show significant differences among samples at $p<0.05$.

The FRAP assay is based on reducing the ferric-tripyridyl triazine complex $\left(\mathrm{Fe}^{3+}\right.$ TPTZ) to ferrous-tripyridyl-triazine ( $\mathrm{Fe}^{2+}$-TPTZ) by antioxidants. The results showed that all Mucuna extracts possessed an interesting iron chelating capacity. Surprisingly, MIT, MMM, and MPR presented FRAP values equal to ascorbic acid as shown in Figure 5. Moreover, MGG possessed the highest FRAP value (901.96 $\mathrm{mg} \mathrm{FeSO} 4$ /g extract) and was significantly higher than ascorbic acid $(p<0.05)$. These results are related to previous reports that indicated the iron-chelating property of Mucuna extracts [18,55]. It can be assumed that Mucuna extract can be a metal-chelating agent and can inhibit metal-induced oxidation reactions.

Stratum corneum is the outermost layer of the skin. It plays a crucial role in maintaining the barrier function of the skin. It is composed of corneocytes (brick) surrounded by a lipid matrix (mortar) [56]. Skin lipid peroxidation can be occurred by various mechanisms, especially free radicals. A previous study reported that natural antioxidants could inhibit lipid peroxidation by donating a hydrogen atom to the lipid peroxyl radicals preventing the propagation of the oxidation [57]. In this study, the results showed that MGG possessed the highest lipid-peroxidation property (IC50 at $4.44 \mathrm{mg} / \mathrm{mL}$ ) compared with other $\mathrm{Mu}$ cuna extracts $(p<0.05)$. This can be explained by the fact that MGG has higher flavonoid content than other Mucuna extracts. Therefore, flavonoids in MGG, which are hydrophobic compounds, were compatible with the system of the lipid peroxidation assay.

\subsection{Anti-Aging Properties}

The anti-aging properties of Mucuna seed extracts can be evaluated by their inhibition against collagenase, elastase, and hyaluronidase. Collagen is a main protein of the extracellular matrix (ECM) in the dermis that can be hydrolyzed by collagenase. The effect of collagen fragmentation is caused by the wrinkling process [58]. Elastin is a protein also found in the dermis that is responsible for the elasticity of the skin [59]. Elastase is an enzyme that can break up elastin and lead to the loss of skin elasticity and skin aging [40]. Moreover, hyaluronic acid or hyaluronan is an essential polysaccharide that holds and 
retains moisture in the skin. Hyaluronidase is a vital enzyme that digests hyaluronic acid and increases the permeability of the tissue [60].

The collagenase- and elastase inhibitory activities of Mucuna seed extracts were compared with those of L-DOPA and EGCG whereas the hyaluronidase inhibitory activity of the extracts was compared with that of L-DOPA and ascorbic acid, as shown in Figure 6. Interestingly, the results revealed that MPR extract (\%inhibition $=55.33 \pm 6.43$ ) and MIT extract (\%inhibition $=53.00 \pm 10.44$ ) showed moderate anti-collagenase activity and were significantly higher than other extracts and EGCG $(p<0.05)$. Due to anti-elastase activity, all extracts possessed mild activity against elastase; however, they had activity equal to EGCG ( $p>0.05)$. L-DOPA is a major component of Mucuna extracts; however, it did not include the main component for anti-collagenase activity. Previous research presented that Mucuna seed extract contains high levels of amino acids, glutathione, lecithin, gallic acid, and beta-sitosterol [61]. Therefore, the anti-collagenase and anti-elastase activities of extracts might be due to phenolic and flavonoid compounds in the extracts.

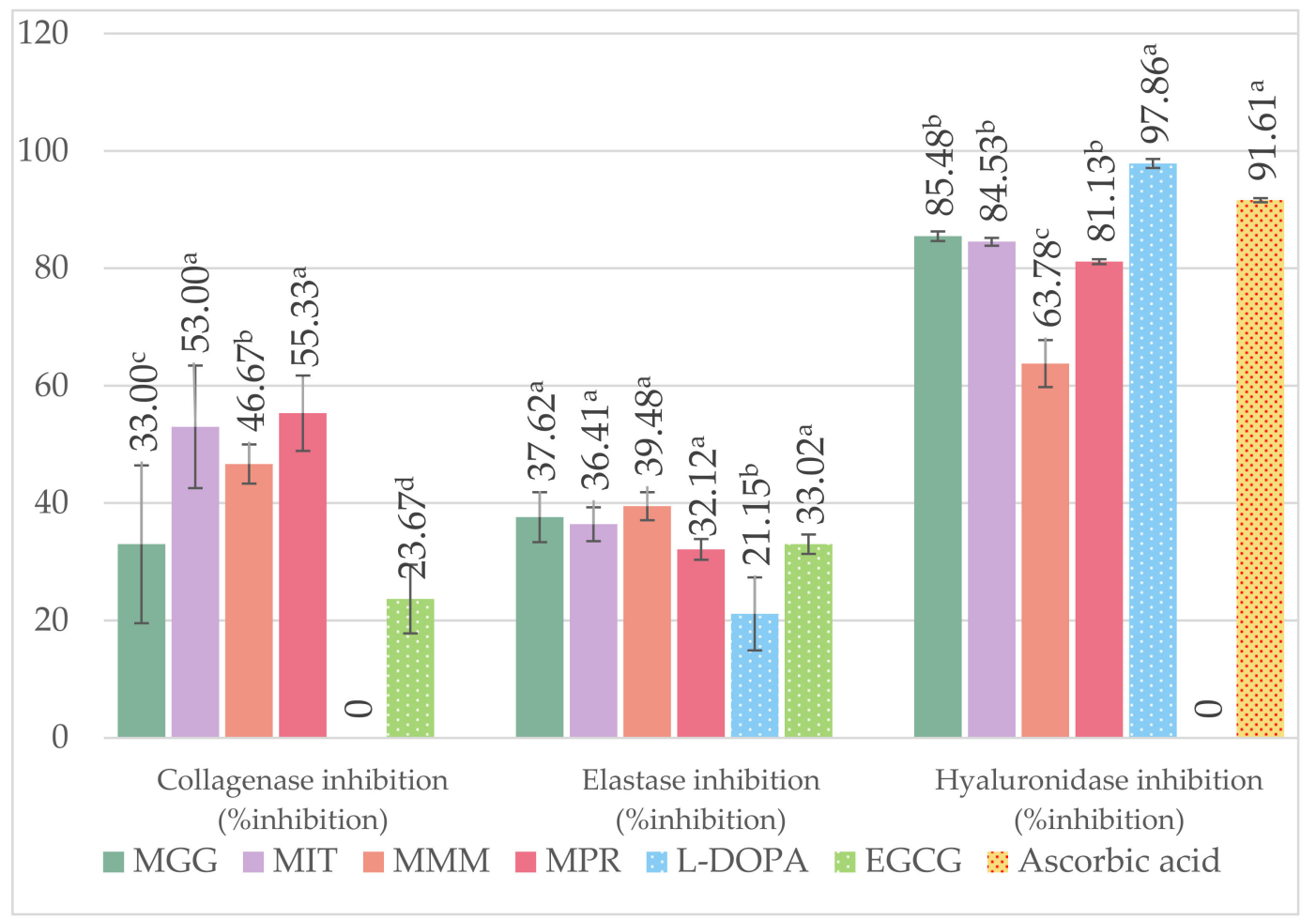

Figure 6. Collagenase, elastase, and hyaluronidase inhibitory activities of Mucuna seed extracts (concentrations $1 \mathrm{mg} / \mathrm{mL}$ ). Values are expressed as mean $\pm \mathrm{SD}(n=3) ; \mathrm{a}, \mathrm{b}, \mathrm{c}$, and d show significant differences among samples at $p<0.05$.

Surprisingly, MGG, MIT, and MPR extracts inhibited strong anti-hyaluronidase activity more than $80 \%$ inhibition. The results also showed that L-DOPA presented the highest antihyaluronidase activity equal to with ascorbic acid $(p>0.05)$. A previous study indicated that $M$. pruriens seed extract was an active ingredient against snake venom, with hyaluronidases as the key enzymes involved in snake venom toxicity [7,62]. However, anti-hyaluronidase activity of L-DOPA from previous studies, in terms of skin-related activity, are limited.

\section{Conclusions}

In conclusion, this study revealed that the morphological analysis integrated with a mini-DNA barcode ITS2 region could authenticate Mucuna seed material. In a phytochemical analysis, L-DOPA was discovered in all Mucuna seeds, of which MPR had the highest L-DOPA content. Meanwhile, the quantities of phenolics and flavonoids were 
found in MGG at the highest content. Based on GC-MS chromatographic profiles, all Mucuna spp. contained miscellaneous phytochemical substances that possessed various biological activities. In the case of skin-related activity, there were no Mucuna samples that showed C. acnes inhibitory activity. However, MMM and MPR exhibited antimicrobial activity against $S$. aureus, S. epidermidis, and C. albicans, which are important microorganisms related to skin microbiota and skin problems. For antioxidant activity, all Mucuna seed extracts presented good properties - to scavenge free radicals, inhibit lipid peroxidation and chelate metal. Interestingly, the ethanolic seed extracts of all four Mucuna species showed strong inhibitory activities against all three skin-related enzymes, collagenase, elastase, and hyaluronidase, compared with chemical standards (L-DOPA, EGCG, and ascorbic acid). Therefore, all Mucuna extracts had interesting potential in controlling the balance of skin barrier functioning and preventing skin aging, including the related processes that promoted skin health. In conclusion, the seeds of these four Mucuna species are promising plant-based ingredients that could be used to further develop cosmeceutical products, especially antiaging formulations. In our next study, we intend to develop a formulation containing Mucuna seed extract, evaluate the skin primary irritation test, and perform clinical trials, including satisfaction with human subjects.

Supplementary Materials: The following are available online at https:/ / www.mdpi.com/article/ 10.3390/cosmetics9010014/s1, Figure S1: Alignment of nucleotide sequences of the ribosomal DNA ITS2 regions of four Mucuna species, Figure S2: Minimal inhibitory concentrations (MICs) of Mucuna seed extracts on skin-related pathogen evaluated by broth micro-dilution and resazurin reduction methods, Table S1: Phytochemical constituents of four Mucuna seed extracts evaluated by GCMS analysis.

Author Contributions: Conceptualization, A.I. and K.K.; methodology, A.I., K.K. and T.T.; software, T.T. and N.N.; validation, T.T. and N.N.; formal analysis, T.T., K.K. and N.N.; investigation, N.N., T.T. and A.I.; resources, A.I.; data curation, A.I. and K.K.; writing-original draft preparation, A.I., K.K. and T.T.; writing-review and editing, A.I., K.K., M.W. and P.C.; visualization, A.I., K.K. and T.T.; supervision, A.I. and K.K.; project administration, A.I.; funding acquisition, A.I. All authors have read and agreed to the published version of the manuscript.

Funding: This research was funded by the new researcher grant from the Thailand Research Fund and Chiang Mai University, grant number MRG6080203.

Institutional Review Board Statement: Not applicable.

Informed Consent Statement: Not applicable.

Data Availability Statement: Not applicable.

Acknowledgments: This work conducted and supported by the Faculty of Pharmacy, including the Innovation Center for Holistic Health, Nutraceuticals, and Cosmeceuticals, Faculty of Pharmacy, Chiang Mai University, Chiang Mai and School of Cosmetic Science, Mae Fah Luang University, Chiang Rai, Thailand. The authors are grateful to Wannaree Charoensup, botanist of the Faculty of Pharmacy, Chiang Mai University, for morphologically identifying the samples of the Mucuna seeds.

Conflicts of Interest: The authors declare no conflict of interest.

\section{References}

1. Moura, T.M.; Vatanparas, M.; Tozzi, A.M.G.A.; Forest, F.; Wilmot-Dear, M.; Simon, M.F.; Mansano, V.F.; Kajita, T.; Lewis, G.P. A Molecular Phylogeny and New Infrageneric Classification of Mucuna Adans. (Leguminosae-Papilionoideae) Including Insights from Morphology and Hypothesis about Biogeography. Int. J. Plant Sci. 2016, 177, 76-89. [CrossRef]

2. Wilmot-Dear, C.M. Mucuna Adams (Leguminosae) in Thailand. Thai. For. Bull. Bot. 2008, 36, 114-139.

3. Leeratiwong, C.; Jornead, S.; Satthaphorn, J.; Chantaranothai, P. A new record of Mucuna Adans. (Leguminosae) for Thailand. Thai. For. Bull. Bot. 2018, 46,1-3. [CrossRef]

4. Sathyanarayana, N.; Leelamabika, M.; Mahesh, S.; Jaheer, M. AFLP assessment of genetic diversity among Indian Mucuna accessions. Physiol. Mol. Biol. Plants 2011, 17, 171-180. [CrossRef]

5. Sungthongwises, K. Diversity of Phosphate Solubilizing Bacteria under Rubber Intercropping. Asian J. Plant Sci. 2016, 15, 75-80. [CrossRef] 
6. Balogun, I.O.; Olatidoye, O.P. Chemical Composition and Nutritional Evaluation of Velvet Bean Seeds (Mucuna utilis) for Domestic Consumption and Industrial Utilization in Nigeria. Pak. J. Nutr. 2012, 11, 116-122. [CrossRef]

7. Lampariello, L.R.; Cortelazzo, A.; Guerranti, R.; Sticozzi, C.; Valacchi, G. The Magic Velvet Bean of Mucuna pruriens. J. Tradit. Complement. Med. 2012, 2, 331-339. [CrossRef]

8. Cilia, R.; Laguna, J.; Cassani, E.; Cereda, E.; Pozzi, N.G.; Isaias, I.U.; Contin, M.; Barichella, M.; Pezzoli, G. Mucuna pruriens in Pakinson disease: A double-blind, randomized, controlled, crossover study. Neurology 2017, 89, 432-438. [CrossRef]

9. Pathak-Gandhi, N.; Vaidya, A.D.B. Management of Parkinson's disease in Ayurveda: Medicinal plants and adjuvant measures. J. Ethnopharmacol. 2017, 197, 46-51. [CrossRef]

10. Damodaran, M.; Ramaswamy, R. Isolation of l-3:4-dihydroxyphynylalanine from the seeds of Mucuna pruriens. Biochem. J. 1937, 31, 2149-2152. [CrossRef]

11. Aware, C.; Patil, R.; Gaikwad, S.; Yadav, S.; Bapat, V.; Jadhav, J. Evaluation of L-dopa, proximate composition with in vitro anti-inflamatory and antioxidant activity of Mucuna macrocarpa beans: A future drug for Parkinson treatment. Asian Pac. J. Trop. Biomed. 2017, 7, 1097-1106. [CrossRef]

12. Soumyanath, A.; Danne, T.; Hiller, A.; Ramachandran, S.; Shinto, L. Analysis of Levodopa Content in Commercial Mucuna pruriens Products Using High-Performance Liquid Chromatography with Fluorescence Detection. J. Altern. Complement. Med. 2018, 24, 182-186. [CrossRef] [PubMed]

13. Rene, M.; Suryawanshi, S.; Patil, R.; Aware, C.; Jadhav, R.; Gaikwad, S.; Singh, P.; Yadav, S.; Bapat, V.; Gurav, R.; et al. Exploring the proximate composition, antioxidant, anti-Parkinson's and anti-inflammatory potential of two neglected and underutilized Mucuna species from India. S. Afr. J. Bot. 2019, 124, 304-310. [CrossRef]

14. Tavares, R.L.; Silvo, A.S.; Campo, A.R.N.; Schuler, A.R.P.; Aquino, J.S. Nutritional Composition, phytochemicals and microbiological quality of the legume, Mucuna pruriens. Afr. J. Biotechnol. 2015, 14, 676-682.

15. Das, D.; Das, S.; Pandey, M.; Bhattacharyay, D. In Silico Analysis of Phytochemicals from Mucuna pruriens (L.) DC against Mycobacterium tuberculosis Causing Tuberculosis. EJMP 2020, 31, 19-24. [CrossRef]

16. Johnson, S.L.; Park, H.Y.; DaSilva, N.A.; Vattem, D.A.; Ma, H.; Seeram, N.P. Levodopa-Reduced Mucuna pruriens Seed Extract Shows Neuroprotective Effects against Parkinson's Disease in Murine Microglia and Human Neuroblastoma Cells, Caenorhabditis elegans, and Drosophila melanogaster. Nutrients 2018, 10, 1139. [CrossRef]

17. Laviada-Castillo, R.E.; Segura-Campos, M.R.; Chan-Zapata, I.; Torres-Romero, J.C.; Guillermo-Cordero, J.L.; Arana-Argáez, V.E Immunosuppressive effects of protein derivatives from Mucuna pruriens on a streptozotocin-induced type 1 diabetes murine model. J. Food Biochem. 2009, 43, e12834. [CrossRef]

18. Jimoh, M.A.; Idris, O.A.; Jimoh, M.O. Cytotoxicity, Phytochemical, Antiparasitic Screening, and Antioxidant Activities of Mucuna pruriens (Fabaceae). Plants 2020, 9, 1249. [CrossRef]

19. Dhanani, T.; Singh, R.; Shah, S.; Kumari, P.; Kumar, S. Comparison of green extraction methods with conventional extraction method for extract yield, L-DOPA concentration and antioxidant activity of Mucuna pruriens seed. Green Chem. Lett. Rev. 2015, 8, 43-48. [CrossRef]

20. Shanmugavel, G.; Krishnamoorthy, G. In vitro evaluation of the antibacterial activity of alcoholic extract from Mucuna pruriens seed. Int. J. Herb. Med. 2015, 2, 7-9.

21. Mutwedu, V.B.; Ayagirwe, R.B.B.; Mwema, L.M.; Butseme, S.; Kashosi, T.; Mitima, B.; Manyawu, G.J.; Nyongesa, A.W. Effect of dietary inclusion of small quantities of Mucuna pruriens seed meal on sexual behavior, semen characteristics in rabbit bucks (Oryctolagus curiculus). Trop. Anim. Health Prod. 2019, 51, 1195-1202. [CrossRef] [PubMed]

22. Ashidi, J.S.; Owagboriaye, F.O.; Yaya, F.B.; Payne, D.E.; Lawal, O.I.; Owa, S.O. Assessment of reproductive function in male albino rat fed dietary meal supplemented with Mucuna pruriens seed powder. Heliyon 2019, 5, e02716. [CrossRef] [PubMed]

23. Chambers, E.S.; Vukmanovic-Stejic, M. Skin barrier immunity and ageing. Immunology 2019, 160, 116-125. [CrossRef] [PubMed]

24. Zhang, S.; Duan, E. Fighting against skin aging: The way from bench to bedside. Cell Transplant. 2018, 27, 729-738. [CrossRef]

25. Parrado, C.; Mercado-Saenz, S.; Perez-Davo, A.; Gilaberte, Y.; Gonzalez, S.; Juarranz, A. Environmental stressors on skin aging mechanistic insights. Front. Pharmacol. 2019, 10, 759. [CrossRef]

26. Tobin, D.J. Introduction to skin aging. J. Tissue Viability 2017, 26, 37-46. [CrossRef] [PubMed]

27. Wang, A.S.; Dreesen, O. Biomarkers of cellular senescence and skin aging. Front. Genet. 2018, 9, 247-260. [CrossRef]

28. Shin, J.-W.; Kwon, S.-H.; Choi, J.-Y.; Na, J.-I.; Huh, C.-H.; Choi, H.-R.; Park, K.-C. Molecular mechanisms of dermal aging and antiaging approaches. Int. J. Mol. Sci. 2019, 20, 2126. [CrossRef]

29. Baumann, L. Skin ageing and its treatment. J. Pathol. 2007, 211, 241-251. [CrossRef] [PubMed]

30. Toole, B.P. Hyaluronan: From extracellular glue to pericellular cue. Nat. Rev. Cancer 2004, 4, 528-539. [CrossRef]

31. Papakonstantinou, E.; Roth, M.; Karakiulakis, G. Hyaluronic acid: A key molecule in skin aging. Derm.-Endocrinol. 2012, 4, 253-258. [CrossRef] [PubMed]

32. Chen, S.; Yao, H.; Han, J.; Liu, C.; Song, J.; Shi, L.; Zhu, Y.; Ma, X.; Gao, T.; Pang, X.; et al. Validation of the ITS2 Region as a Novel DNA Barcode for Identifying Medicinal Plant Species. PLoS ONE 2010, 5, e8613. [CrossRef] [PubMed]

33. Sheidai, M.; Tabaripour, R.; Talebi, S.M.; Noormohammadi, Z.; Koohdar, F. Adulteration in medicinally important plant species of Ziziphora in Iran market: DNA barcoding approach. Ind. Crops Prod. 2019, 130, 627-633. [CrossRef]

34. Poomanee, W.; Wattananapakasem, I.; Panjan, W.; Kiattisin, K. Optimizing anthocyanins extraction and the effect of cold plasma treatment on the anti-aging potential of purple glutinous rice (Oryza sativa L.) extract. Cereal Chem. 2021, 98, 571-582. [CrossRef] 
35. Zargoosh, Z.; Ghavam, M.; Bacchetta, G.; Tavili, A. Effects of ecological factors on the antioxidant potential and total phenol content of Scrophularia stricta Boiss. Sci. Rep. 2019, 9, 16021. [CrossRef]

36. Yaraksa, N.; Anunthawan, T.; Theansungnoen, T.; Daduang, S.; Araki, T.; Dhiravisit, A.; Thammasirirak, S. Design and synthesis of cationic antibacterial peptide based on Leucrocin I sequence, antibacterial peptide from crocodile (Crocodylus siamensis) white blood cell extracts. J. Antibiot. 2014, 67, 205-212. [CrossRef]

37. Theansungnoen, T.; Yaraksa, N.; Daduang, S.; Dhiravisit, A.; Thammasirirak, S. Purification and characterization of antioxidant peptides from leukocyte extract of Crocodylus siamensis. Protein J. 2014, 33, 24-31. [CrossRef]

38. Nitthikan, N.; Leelapornpisid, P.; Natakankitkul, S.; Chaiyana, W.; Mueller, M.; Viernstein, H.; Kiattisin, K. Improvement of stability and transdermal delivery of bioactive compounds in green robusta coffee beans extract loaded nanostructured lipid carriers. J. Nanotechnol. 2018, 2018, 7865024. [CrossRef]

39. Widowati, W.; Rani, A.P.; Hamzah, R.A.; Arumwardana, S.; Afifah, E.; Kusuma, H.S.W.; Rihibiha, D.D.; Nufus, H.; Amalia, A Antioxidant and antiaging assays of Hibiscus sabdariffa extract and its compounds. Nat. Prod. Sci. 2017, 23, 192-200. [CrossRef]

40. Thring, T.S.A.; Hili, P.; Naughton, D.P. Anti-collagenase, anti-elastase and anti-oxidant activities of extracts from 21 plants. BMC Complement. Med. Ther. 2009, 9, 27. [CrossRef] [PubMed]

41. Drouet, S.; Garros, L.; Hano, C.; Tungmunnithum, D.; Renouard, S.; Hagège, D.; Maunit, B.; Laine, È. A Critical View of Different Botanical, Molecular, and Chemical Techniques Used in Authentication of Plant Materials for Cosmetic Applications. Cosmetics 2018, 5, 30. [CrossRef]

42. Narayana, D.B.; Johnson, S.T. DNA barcoding in authentication of herbal raw materials, extracts and dietary supplements: A perspective. Plant Biotechnol. Rep. 2019, 13, 201-210. [CrossRef]

43. Moorhouse-Gann, R.J.; Dunn, J.C.; de Vere, N.; Goder, M.; Cole, N.; Hipperson, H.; Symondson, W.O.C. New universal ITS2 primers for high-resolution herbivory analyses using DNA metabarcoding in both tropical and temperate zones. Sci. Rep. 2018, 8, 8542. [CrossRef]

44. Rashmi, R.V.; Sathyanarayana, N.; Vidya, S.M. Validation of DNA barcoding markers in common Mucuna species of India for taxonomy and pharmacognosy applications. Plant Gene 2017, 12, 98-104.

45. Demidchik, V. Mechanisms of oxidative stress in plants: From classical chemistry to cell biology. Environ. Exp. Bot. 2015, 109, 212-228. [CrossRef]

46. Saravanakumar, K.; Chelliah, R.; Hu, X.; Oh, D.H.; Kathiresan, K.; Wang, M.H. Antioxidant, Anti-Lung Cancer, and Anti-Bacterial Activities of Toxicodendron vernicifluum. Biomolecules 2019, 9, 127. [CrossRef]

47. Wang, J.; Liu, H.; Gao, H.; Zhao, J.; Zhao, L.; Han, J.; Yu, Z.; Yang, F. Antimicrobial and antioxidant activities of the flower essential oil of Halimodendron halodendron. Nat. Prod. Commun. 2011, 6, 1749-1753. [CrossRef]

48. Ahmad, S.; Ullah, F.; Sadiq, A.; Ayaz, M.; Imran, M.; Ali, I.; Zeb, A.; Ullah, F.; Shah, M.R. Chemical composition, antioxidant and anticholinesterase potentials of essential oil of Rumex hastatus D. Don collected from the North West of Pakistan. BMC Complement Altern. Med. 2016, 16, 29. [CrossRef]

49. Babaiwa, U.F.; Erharuyi, O.; Falodun, A.; Akerele, J.O. Antimicrobial activity of ethyl acetate extract of Citrullus lanatus seeds. Trop. J. Pharm. Res. 2017, 16, 1631-1636. [CrossRef]

50. Yang, J.F.; Liang, M.T.; Yang, C.H.; Gao, Z.J.; Wu, Y.W.; Chuang, L.Y. Chromatographic-mass spectrometric analysis of ethanol extract of Maesa perlaria var. formosana. Trop. J. Pharm. Res. 2016, 15, 1025-1029. [CrossRef]

51. Butler, C.R.; Beck, E.M.; Harris, A.; Huang, Z.; McAllister, L.A.; am Ende, C.W.; Fennell, K.; Foley, T.L.; Fonseca, K.; Hawrylik, S.J.; et al. Azetidine and Piperidine Carbamates as Efficient, Covalent Inhibitors of Monoacylglycerol Lipase. J. Med. Chem. 2017, 60, 9860-9873. [CrossRef] [PubMed]

52. Manjuntha, B.K.; Patil, H.S.R.; Vidya, S.M.; Kekuda, T.R.P.; Mukunda, S.; Davikar, R. Studies on the antibacterial activity of Mucuna monosperma. Indian Drugs 2006, 43, 150-152.

53. Natarajan, K.; Narayanan, N.; Ravichandran, N. Pharmacognostical characterization, phytochemical and antimicrobial evaluation of Mucuna cochinchinensis (lour.) Cheval seeds. J. Pharm. Res. 2013, 6, 318-323. [CrossRef]

54. Longhi, J.G.; Perez, E.; de Lima, J.J.; Cândido, L.M.B. In vitro evaluation of Mucuna pruriens (L.) DC. antioxidant activity. Braz. J. Pharm. Sci. 2011, 47, 535-544. [CrossRef]

55. Dhanasakaran, M.; Tharakan, B.; Manyam, B.V. Antiparkinson drug-Mucuna pruriens shows antioxidant and metal chelating activity. Phytother. Res. 2008, 22, 6-11. [CrossRef]

56. Lefèvre-Utile, A.; Braun, C.; Haftek, M.; Aubin, F. Five functional aspects of the epidermal barrier. Int. J. Mol. Sci. 2021, $22,11676$. [CrossRef]

57. Félix, R.; Valentão, P.; Andrade, P.B.; Félix, C.; Novais, S.C.; Lemos, M.F. Evaluating the in vitro potential of natural extracts to protect lipids from oxidative damage. Antioxidants 2020, 9, 231. [CrossRef] [PubMed]

58. Mukherjee, P.K.; Maity, N.; Nema, N.K.; Sarkarm, B.K. Bioactive compounds from natural resources against skin aging. Phytomedicine 2011, 19, 64-73. [CrossRef]

59. Fulop, T.; Khalil, A.; Larbi, A. The role of elastin peptides in modulating the immune response in aging and age-related diseases Pathol. Biol. 2012, 60, 28-33. [CrossRef]

60. Bravo, K.; Alzate, F.; Osorio, E. Fruits of selected wild and cultivated Andean plants as sources of potential compounds with antioxidant and anti-aging activity. Ind. Crops Prod. 2016, 85, 341-352. [CrossRef] 
61. Pathania, R.; Chawla, P.; Khan, H.; Kaushik, R.; Khan, M.A. An assessment of potential nutritive and medicinal properties of Mucuna pruriens: A natural food legume. Biotech 2020, 10, 261. [CrossRef] [PubMed]

62. Santhosh, M.S.; Hemshekhar, M.; Sunitha, K.; Thushara, R.M.; Jnaneshwari, S.; Kemparaju, K.; Girish, K.S. Snake venom induced local toxicities: Plant secondary metabolites as an auxiliary therapy. Mini-Rev. Med. Chem. 2013, 13, 106-123. [CrossRef] [PubMed] 